\title{
Weeding Frequencies Improve Soil Available Nitrogen in Organic Paddy Field
}

\author{
DOI 10.18196/pt.v10i1.12707
}

\author{
Margi Asih Maimunah, ${ }^{1,2}$, Valensi Kautsar ${ }^{3,4}$, Putu Oki Bimantara ${ }^{2}$, Samuel Munyaka Kimani ${ }^{3}$, \\ Asih Indah Utami ${ }^{1,2}$, Riza Kurnia Sabri ${ }^{1,2}$, Keitaro Tawaraya ${ }^{2,3}$, Sri Nuryani Hidayah Utami ${ }^{1}$, \\ Benito Heru Purwanto ${ }^{1^{*}}$, Weiguo Cheng ${ }^{2,3}$ \\ ${ }^{1}$ Faculty of Agriculture, Universitas Gadjah Mada, Indonesia, Jl. Flora, Bulaksumur - Yogyakarta 55281, Indonesia \\ ${ }^{2}$ Faculty of Agriculture, Yamagata University, 1-23, Wakaba-machi, Tsuruoka-shi, Yamagata, 997-8555, Japan \\ ${ }^{3}$ The United Graduate School of Agricultural Sciences, Iwate University, Japan, 3-chome-18 Ueda, Morioka, Iwate 020-0066, Japan \\ ${ }^{4}$ Faculty of Agriculture, Stiper Agricultural University, Maguwoharjo, Depok, Sleman, Yogyakarta, 55282, Indonesia \\ "Corresponding author, email: benito@ugm.ac.id
}

\begin{abstract}
Appropriate weeds control is needed against weeds constraints in field, especially the organic field. With the appropriate management, weeding would benefit the organic field not only in reducing weeds but also in increasing nitrogen $(\mathrm{N}$ ) availability in organic rice fields. This research aims to observe soil available $N$ changes affected by weeding frequencies in organic paddy fields. Treatments applied were five weeding frequencies (WF) such as 0 WF, 2 $\mathrm{WF}, 4 \mathrm{WF}, 6 \mathrm{WF}$, and $8 \mathrm{WF}$, to study the effect of various weeding frequencies on soil total $\mathrm{N}$ and available $\mathrm{N}\left(\mathrm{NH}_{4}{ }^{+}\right.$and $\mathrm{NO}_{3}{ }^{-}$) in the organic rice field. The soil in the conventional field was analyzed as a comparison to organic field soil. The results showed that soil $\mathrm{C}$ and $\mathrm{N}$ contents are similar in all treatments. Meanwhile, 6 WF performed the highest soil $\mathrm{NH}_{4}{ }^{+}$among organic plots (10.36 mg N kg-1) and 8 WF enhanced soil NO3- to the highest average among all plots (10.12 mg N kg-1). The treatment of $6 \mathrm{WF}$ and $8 \mathrm{WF}$ also maintain the increase of soil $\mathrm{NH}_{4}{ }^{+}$to 51 days after transplanting (DAT), meanwhile $0 \mathrm{WF}, 2 \mathrm{WF}$, and $4 \mathrm{WF}$ decreased after $40 \mathrm{DAT}$. Water samples from fields inlet-outlet and river showed that $\mathrm{NH}_{4}{ }^{+}$content found in water sample was higher than NO3-. We concluded that the more frequencies of weeding applied to organic fields potentially preserved soil inorganic N longer, which is very important in supporting rice growth.
\end{abstract}

Keywords: Ammonium, Nitrate, Intensity of weeding, Organic weeds management, Rotary weeder

\begin{abstract}
ABSTRAK
Pengendalian gulma yang tepat diperlukan untuk mengatasi kendala gulma di lahan, terutama di lahan organik. Dengan pengelolaan yang tepat, penyiangan akan bermanfaat bagi lahan organik tidak hanya dalam mengurangi gulma tetapi juga dalam meningkatkan ketersediaan nitrogen (N) di lahan sawah organik. Penelitian ini bertujuan untuk mengamati perubahan N tersedia tanah yang dipengaruhi oleh frekuensi penyiangan di lahan sawah organik. Perlakuan yang diberikan adalah lima frekuensi penyiangan (WF) yaitu 0 WF, 2 WF, 4 WF, 6 WF, dan 8 WF, untuk mempelajari pengaruh berbagai frekuensi penyiangan terhadap $\mathrm{N}$ total tanah dan $\mathrm{N}$ tersedia $\left(\mathrm{NH}_{4}^{+}\right.$dan $\left.\mathrm{NO}_{3}^{-}\right)$di tanah sawah organik. Tanah di lahan konvensional dianalisis sebagai pembanding dari tanah di lahan organik. Hasil penelitian menunjukkan bahwa kandungan C dan N tanah memiliki nilai serupa pada semua perlakuan. Sementara itu, 6 WF memiliki kandungan NH4+ tanah tertinggi di antara plot organik (10,36 mg N kg-1) dan 8 WF meningkatkan $\mathrm{NO}_{3}^{-}$tanah dengan rerata tertinggi di antara semua plot (10,12 mg N kg-1). Perlakuan 6 WF dan 8 WF juga terbukti dapat mempertahankan peningkatan NH ${ }_{4}^{+}$tanah hingga 51 hari setelah tanam (HST), sedangkan pada O WF, 2 WF, dan 4 WF terjadi penurunan setelah 40 HST. Sampel air dari inlet-outlet sawah dan sungai menunjukkan bahwa kandungan $\mathrm{NH}_{4}^{+}$yang ditemukan dalam sampel air lebih tinggi dari $\mathrm{NO}_{3}^{-}$. Kami menyimpulkan bahwa penambahan frekuensi penyiangan yang diberikan pada lahan organik berpotensi mengawetkan N tersedia tanah lebih lama, yang sangat penting dalam mendukung pertumbuhan padi.
\end{abstract}

Kata kunci: Amonium, Nitrat, Intensitas penyiangan, Pengendalian gulma organik, alat pemotong gulma putar

\section{INTRODUCTION}

Rice is a staple food for people in the world, and physiology of rice, weed, and soil fauna and especially in most parts of Asia (Muthayya et al., microbial. While the physical environmental fac2014; Phukan et al., 2021). The sustainability of rice tors, which there are climatic and soil factors (Long production faces challenges from various factors, and Yabe, 2011; Bhatia et al., 2016; Wu et al., 2018). including biological factors and physical environ- The presence of weeds in rice paddy fields mental factors. Biological factors include genetics involve serious problem and tremendously affect

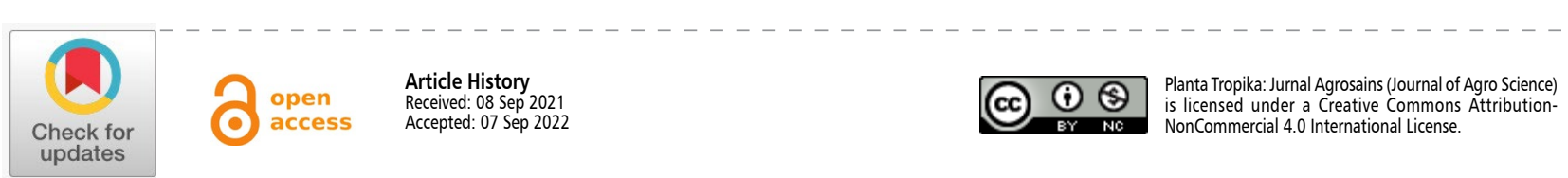


rice production in quality and yield (Bajwa et al., 2015; Peng et al., 2021). Rice qualities are affected by weeds, such as crop bending and leaf rolling (Peng et al., 2021). The injuries caused by weeds would potentially impact rice growth and yield. Weeds caused yield losses with a range that was influenced by factors such rice management and ecosystem, rice cultivar, growth rate, and weeds itself (density and species) (Chauhan et al., 2014). The loss potential had been estimated at 35 to $47 \%$ in rice production (Johnson et al., 2004; Oerke and Dehne, 2004).

Herbicides were effective in removing weeds and increasing food production (Hikosaka et al., 2021). Herbicide development began in World War II, also known as the 'chemical era'. Herbicides are used to control weeds to date and are reported as the highest pesticide product, approximately $47.6 \%$ of global pesticide sales, followed by insecticides (29.4\%), fungicides (17.5\%), and others (5.5\%)(Vats, 2015). Excessive use of herbicides causes a decrease in biodiversity, serious environmental and ecological issues on rice paddy fields, so that alternative methods have been considered to be applied (Li et al., 2019; Sardana et al., 2017). According to the terms of organic agriculture, nonchemical weeding was applied to control the weeds population (Bhatia et al., 2016). Suitable periods of weeding in the organic field decreased weeds and optimized crop yield (Latif et al., 2021; Phukan et al., 2021; Uno et al., 2021). Latif et al (2021) concluded that hoeing at 15 days after transplanting (DAT) followed by 30 DAT was the best treatment. Moreover, weeding in late periods was negatively affected growth and yield parameters.

Not only controlling weeds, but the organic farm also faces the hardship in supplying nutrients for the crops. The soil in organic rice fields cannot supply nutrients, especially $\mathrm{N}$, as the conventional field. Weed exist in the fields, causing competition in nutrient uptake that will inhibit rice growth on reaching potential yield (Hazra et al., 2018; Martínez-Eixarch et al., 2017). While, deficiency of $\mathrm{N}$ has been a primary constraint in lowland rice productivity (Sahrawat, 2006). Nitrogen (N) has been known as an essential and labile nutrient in the paddy field. Paddy soils capability in supplying $\mathrm{N}$ has a high impact on rice yield (Dewi et al., 2018; Ishii et al., 2011; Nguyen et al., 2020).

Moreover, incorporating weeds contributed to scavenged soil nitrogen (Huang et al., 2018); suppressed weed growth, increased the amount of inorganic nitrogen (Ardiantika et al., 2018; Utami et al., 2020); mineralizable soil nitrogen (Tanaka et al., 2012; Toriyama et al., 2020); and soil available Phosphorus (Sakuraoka et al., 2018). It is indicated that weeding practices and weed returning to the soils will increase and provide available nitrogen for rice. Previous research has established that $21.2 \%$ of the total mineralizable soil $\mathrm{N}$ formed originally from weed, while $78.8 \%$ was from indigenous soil organic $\mathrm{N}$ after years (Toriyama et al., 2020). This proves that in organic rice, weeds must be managed to make a significant contribution to the availability of $\mathrm{N}$.

In Japan, rice straw (RS) is commonly incorporated into the soil after harvest to maintain the fertility of paddy soil (Nguyen et al 2020). This method has been applied in this organic research field for 10 years. Other than that, weeds biomass also left decomposed naturally in the field. Related to farmer habits in controlling weeds using rotary weeder, we assumed that the addition of frequencies in weeding application would have roles in controlling weeds and supplying more soil $\mathrm{N}$ in the organic field, which would support optimizing rice growth. Research in weeds management is essential, especially in the organic field, to reach optimum yield. Moreover, the relation between weed pressure and soil fertility is important to be studied 
(Bhatia et al., 2016; Jerkins and Ory, 2016). Our research aimed to find the most effective weeding frequencies in supplying soil $\mathrm{N}$ in the organic fields, especially soil inorganic $\mathrm{N}$. To reach the purpose of this study, we applied different frequencies of weeding in the early stage of rice growth.

\section{MATERIALS AND METHODS}

Experimental field and management

This experiment was located at Yamagata University Farm, Tsuruoka, Yamagata prefecture, northeastern Japan (3841'55 N 13949'15 E) (Figure 1). The soil in Trsuruoka was classified as Inceptisols. Two fields were observed, organic and conventional rice fields; each field size was 30 x 100 $\mathrm{m}$. One of the popular Japanese rice cultivar, $\mathrm{cv}$. Sasanishiki was transplanted on May 25 ${ }^{\text {th }}, 2019$, and harvested on September $23^{\text {rd }}, 2019$. The planting distance was $32 \times 15 \mathrm{~cm}$ in the organic fields and $30 \times 15 \mathrm{~cm}$ in the conventional fields. The irrigation system was technical irrigation, where the outlet was directed to the river between organic and conventional fields.
Fertilizer and herbicide were applied in the conventional field, while no fertilizer was applied in the organic field. In ten years, mechanical weeding with rotary weeder was applied to control the organic fields by disturbing inter-row weeds. Treatment in this study was weeding frequencies in the organic field. There were five weeding frequencies (WF) treatments, namely, 0 WF, 2 WF, 4 WF, 6 WF, dan $8 \mathrm{WF}$, with four replications for each treatment. All weeding frequencies were applied from 7 to 49 DAT (days after transplanting).

\section{Soil sampling and analysis}

The soil was sampled four times using a hand trowel from the surface layer $(0-1 \mathrm{~cm})$ and sublayer $(1-10 \mathrm{~cm})$ soil depth at 18, 29, 40, and 51 DAT. In addition, three other soil samples (at 60, 88 and 110 DAT) were taken when taking plant samples using a metal frame. The total soil samples were seven times during the growth of rice plants. The data surface layer and sublayer were calculated using the arithmetic mean of $0-10 \mathrm{~cm}$ depth. Concentration of $\mathrm{NH}_{4}^{+}$(ammonium) and $\mathrm{NO}_{3}^{-}$(nitrate)

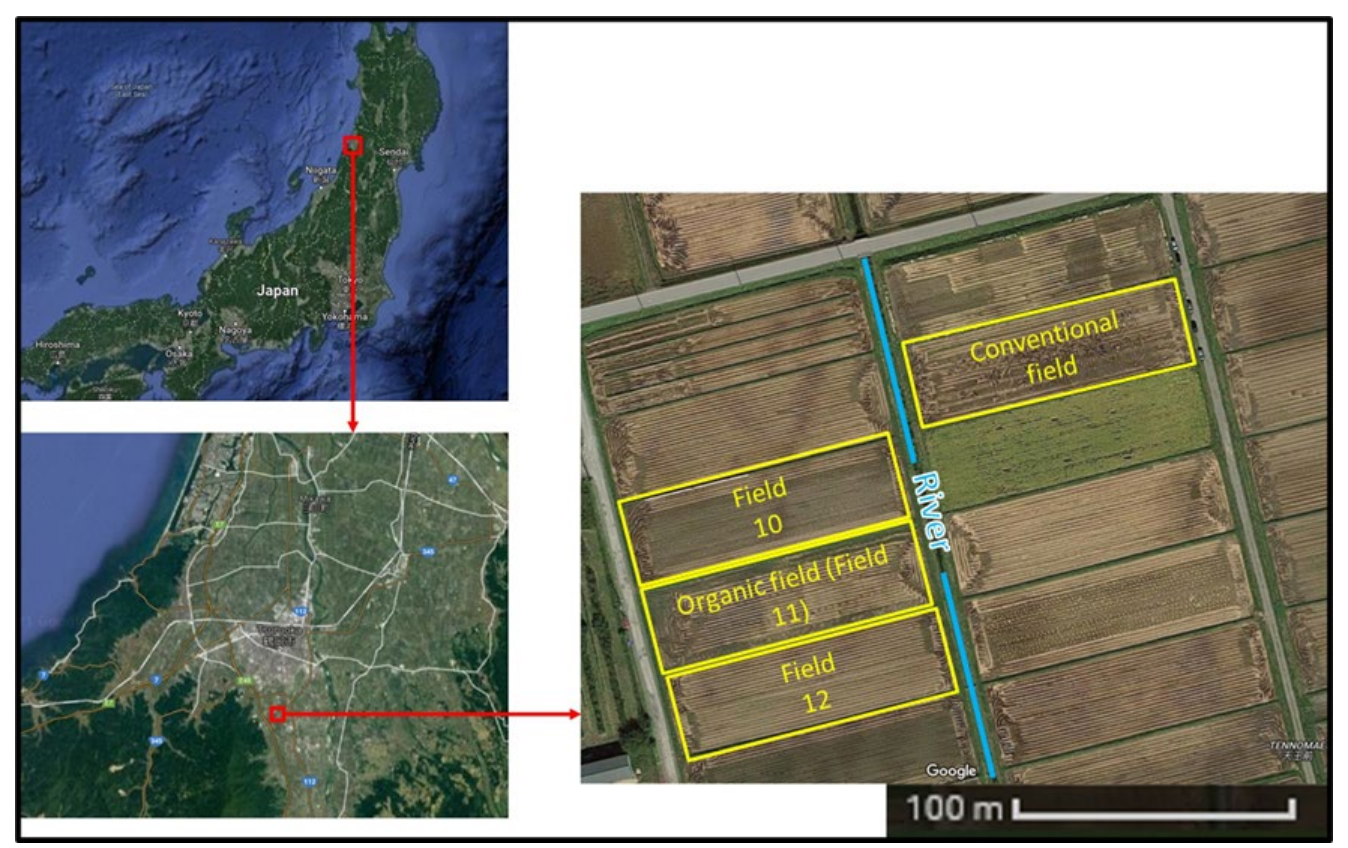

Figure 1. Research location in Yamagata University Farm, Takasaka, Tsuruoka, Japan (Source: https://www.google.com/maps) 
Table 1. Effect of weeding frequencies on soil organic carbon (SOC), total nitrogen (TN) at 110 DAT (days after transplanting).

\begin{tabular}{lll}
\hline Treatments & SOC $(\mathrm{g} \mathrm{C} \mathrm{kg-1)} \pm$ SD & TN $(\mathrm{g} \mathrm{N} \mathrm{kg}-1) \pm S D$ \\
\hline $0 \mathrm{WF}$ & $19.45 \pm 3.49 \mathrm{a}$ & $1.73 \pm 0.29 \mathrm{~b}$ \\
$2 \mathrm{WF}$ & $18.95 \pm 1.18 \mathrm{a}$ & $1.67 \pm 0.17 \mathrm{~b}$ \\
$4 \mathrm{WF}$ & $19.47 \pm 1.29 \mathrm{a}$ & $1.76 \pm 0.18 \mathrm{~b}$ \\
$6 \mathrm{WF}$ & $19.91 \pm 3.88 \mathrm{a}$ & $1.83 \pm 0.34 \mathrm{~b}$ \\
$8 \mathrm{WF}$ & $20.85 \pm 1.31 \mathrm{a}$ & $1.87 \pm 0.11 \mathrm{~b}$ \\
Conventional & $21.94 \pm 1.88 \mathrm{a}$ & $1.87 \pm 0.15 \mathrm{~b}$ \\
\hline
\end{tabular}

Remarks: 0 WF, 2 WF, 4 WF, 6 WF, and 8 WF were $0,2,4,6$, and 8 times mechanical weeding until 49 DAT. Values followed by the same letter in the same column are not significantly different according to Tukey's HSD $(p<0.05)$ test.

were extracted by $5 \mathrm{~g}$ of fresh soil using $30 \mathrm{ml}$ of $10 \% \mathrm{KCl}$. Then, analysed by the nitroprusside and hydrazine reduction methods, respectively. Hitachi U-2900 Spectrophotometer (Hitachi High-Tech Science Corporation, Tokyo, Japan) was used for $\mathrm{NH}_{4}^{+}$and $\mathrm{NO}_{3}{ }^{-}$reading of absorbance at $655 \mathrm{~nm}$ and $540 \mathrm{~nm}$, respectively. Soil organic carbon and total nitrogen were measured by dry combustion method using Sumigraph NC 220F Analyzer (Sumika Chemical Analysis Service, Ltd., Osaka, Japan).

\section{Water sampling and analysis}

Water samples were collected at 18, 29, 40, and 51 DAT. The location for water sampling was located in the river and each field water inlet and outlet. All samples were placed in plastic bottles then filtered using filter paper (Advantec 6, Toyo Roshi Kaisha, Ltd., Japan). Inorganic nitrogen $\left(\mathrm{NH}_{4}^{+}\right.$and $\left.\mathrm{NO}_{3}^{-}\right)$was determined by the same method as soil analysis.

\section{Statistical analysis}

One-way analysis of variance (ANOVA) was applied to compare the difference in all parameters, and means between treatments were compared by Tukey's HSD (honestly significant difference) at $p$ $<0.05$. All statistical analyses were conducted in SPSS 22.0 for Windows (IBM Corp., Armonk, NY, USA).

\section{RESULTS AND DISCUSSION}

Soil carbon and nitrogen

Weeding frequencies was not influenced soil organic carbon (SOC) and total nitrogen (TN) concentration significantly (Table 1). SOC and $\mathrm{TN}$ in organic plot were not significantly different compared to conventional. These results indicated that weeding could not significantly influence SOC and TN in one season. Among weeding frequencies, $8 \mathrm{WF}$ had the closest soil $\mathrm{C}$ and $\mathrm{N}$ concentration to the conventional plot reaching the highest soil C and N. Moreover, 8 WF also had the same concentration of soil $\mathrm{N}$ with the conventional plot.

Soil $\mathrm{NH}_{4}^{+}$in $4 \mathrm{WF}, 6 \mathrm{WF}$, and $8 \mathrm{WF}$ was increased at 29 to 40 DAT (Figure 2a). The highest soil $\mathrm{NH}_{4}^{+}$was in $6 \mathrm{WF}\left(25.27 \mathrm{mg} \mathrm{N} \mathrm{kg}{ }^{-1}\right)$ and 8 WF $\left(24.27 \mathrm{mg} \mathrm{N} \mathrm{kg}^{-1}\right)$ in 51 DAT that differently significant with other treatments $(P<0.05)$. Moreover, $6 \mathrm{WF}$ and $8 \mathrm{WF} \mathrm{NH}_{4}^{+}$were continued to increase and reached the peak at 51 DAT and then decreased. After that, soil $\mathrm{NH}_{4}{ }^{+}$was relatively constant from 60 DAT to 110 DAT in all weeding frequencies. Meanwhile conventional field reached soil $\mathrm{NH}_{4}^{+}$peak in 29 DAT and then constantly decreased (Figure 3).

There was an increment on soil $\mathrm{NO}_{3}{ }^{-}$up to 40 DAT in all treatments (Figure 2A). Similar to soil $\mathrm{NH}_{4}^{+}$, OWF performed lowest in soil $\mathrm{NO}_{3}{ }^{-}$at all sampling periods that was counted in average by $7.82 \mathrm{mg} \mathrm{N} \mathrm{kg}^{-1}$. Whereas 8WF soil reached the 


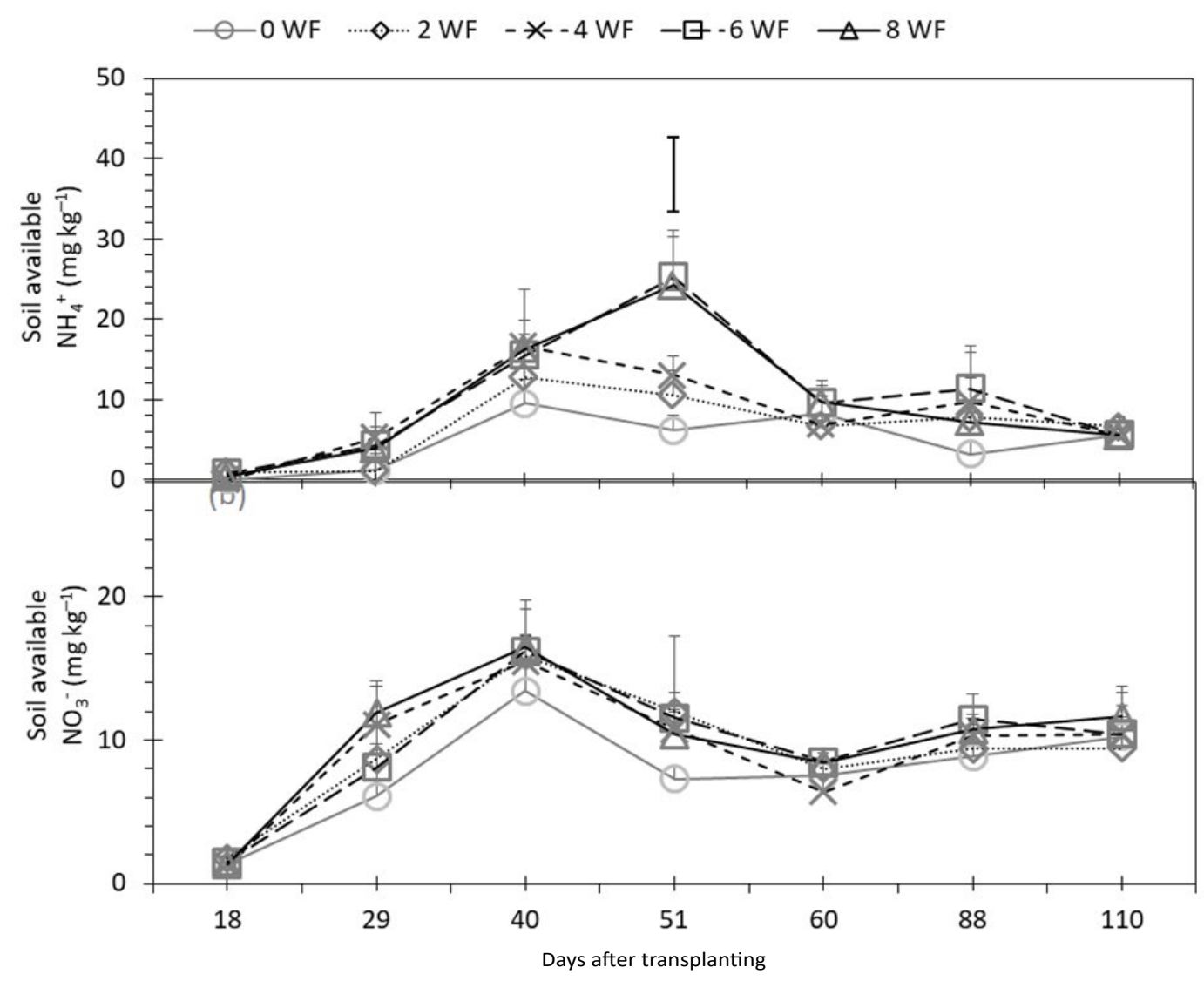

Figure 2. Effects of weeding frequencies on (a) $\mathrm{NH} 4+$ concentration in organic field, (b) NO3- concentration in organic field at $18,29,40,51,60,88$, and 110 DAT (days after transplanting). Bars in each value indicate standard deviation ( $n=4)$. Thick bar over standard deviation bar showed statistically different at $p<0.05$ based on Tukey's HSD test. 0 WF, 2 WF, 4 WF, 6 WF, and 8 WF were $0,2,4,6$, and 8 mechanical weeding frequencies until 49 DAT.

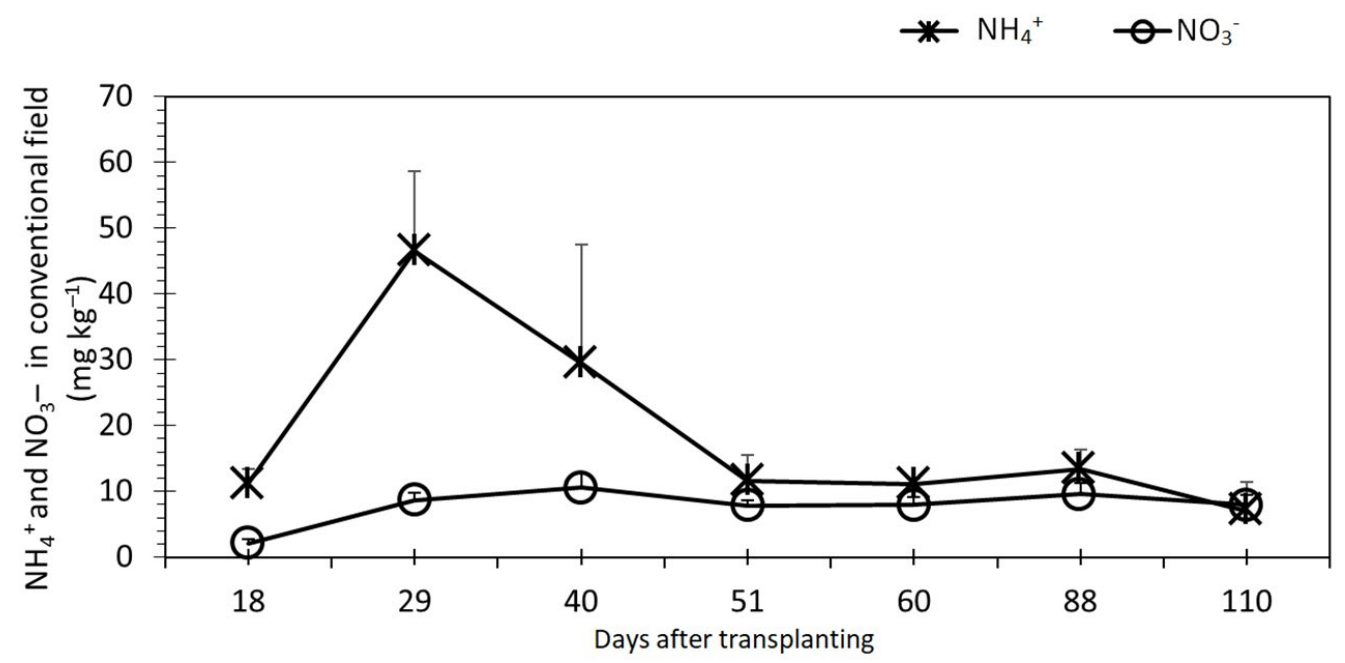

Figure 3. Soil NH4+ and NO3- in conventional field at 18, 29, 40, 51, 60, 88, and 110 DAT (days after transplanting). Bars in each value indicate standard deviation $(n=4)$. 
highest nitrate in the average of $10.12 \mathrm{mg} \mathrm{N} \mathrm{kg}^{-1}$. The soil in the conventional fields reached the peak of $\mathrm{NH}_{4}^{+}\left(38.62 \mathrm{mg} \mathrm{N} \mathrm{kg}{ }^{-1}\right)$ at 29 DAT sampling periods (Figure 3$)$. Then gradually decreased until 110 DAT, but still occupied as the highest in 110 DAT, $6.80 \mathrm{mg} \mathrm{N} \mathrm{kg}^{-1}$. Meanwhile, soil $\mathrm{NO}_{3}^{-}$in conventional was lower than organic plot, and

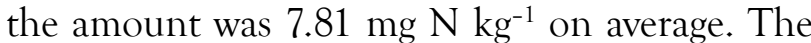
changes of conventional soil $\mathrm{NO}_{3}{ }^{-}$were increased until 40 DAT and tended to have stable amounts until 110 DAT.

Weeding frequencies did not differ significantly in SOC or TN $(P>0.05)$. Yet, there was a slight increase in both parameters with the highest SOC and TN in conventional $\left(21.94 \mathrm{~g} \mathrm{C} \mathrm{kg}^{-1}\right.$ and $1.87 \mathrm{~g}$ $\left.\mathrm{N} \mathrm{kg}^{-1}\right)$ and $8 \mathrm{WF}\left(20.85 \mathrm{~g} \mathrm{C} \mathrm{kg}^{-1}\right.$ and $\left.1.87 \mathrm{~g} \mathrm{~N} \mathrm{~kg}^{-1}\right)$ (Table 1). These findings contrast with de Rouw and Rajot (2004) mentioned that organic matter increment in wheat fields without weed control caused by weed biomass was grown optimum and supplied more carbon than field applied weeds removal. The difference may be caused by different field management, which there was manure spreading that supported weed's growth (de Rouw and Rajot, 2004).

The amount of $\mathrm{NH}_{4}^{+}$was found higher than $\mathrm{NO}_{3}{ }^{-}$due to a flooded irrigating system that supported soil with $\mathrm{NH}_{4}{ }^{+}$through ammonification (Hantush et al., 2013; Liu et al., 2008; Utami et al., 2020; Zhang and Scherer, 2000). Ishii et al. (2011) mentioned that nitrification and denitrification occurs in different places. Nitrification $\left(\mathrm{NH}_{4}^{+} \rightarrow\right.$ $\left.\mathrm{NO}_{2}{ }^{-} \rightarrow \mathrm{NO}_{3}{ }^{-}\right)$was in the thin oxidized soil surface layer, whereas denitrification $\left(\mathrm{NO}_{3}{ }^{-} \rightarrow \mathrm{NO}_{2}{ }^{-} \rightarrow\right.$ $\mathrm{NO} \rightarrow \mathrm{N}_{2} \mathrm{O} \rightarrow \mathrm{N}_{2}$ ) occurs within a reduced soil layer below the oxidized layer. Mostly, nitrate is drained in the reduced soil below the thin oxidized layer at the surface, this mechanism is related to high denitrification activity (Nojiri et al., 2020).
Conventional fields showed the highest NH4+ since the early rice growth stage due to nitrogen fertilizer application (Figure 3). Whereas soil NH4+ in the organic field, much less found in this field only rely on decomposed weed biomass residue and rice straw from previous growing seasons. This condition occurred due to $\mathrm{N}$ supply rate from fertilizer being faster than weeds and rice biomass decomposition.

Soil inorganic $\mathrm{N}$ in early periods showed in low amount. Then, ammonium and nitrate were slowly increased in the organic field due to the activity of weeding applied where soil $\mathrm{NH}_{4}^{+} 6 \mathrm{WF}$ and $8 \mathrm{WF}$ was highest, compared to other treatments. Besides, ammonium and nitrate were slowly increased in the organic field due to the decomposition of organic matter or mineralization (Ishii et al., 2011). In this study, $\mathrm{NH}_{4}^{+}$and $\mathrm{NO}_{3}{ }^{-}$could be produced from the remaining rice straw and weeds decomposition. In line with Maimunah et al. (2021), adding more weeds (in weeding practical) increased the $\mathrm{N}$ concentration of both rice and weeds. Then, the returns of plants biomass could support a high amount of $\mathrm{NH}_{4}^{+}$in the organic fields.

This study found in the organic field that $6 \mathrm{WF}$ was found to perform highest $\mathrm{NH}_{4}^{+}(10.36 \mathrm{mg} \mathrm{N}$ kg-1 in average) and highest $\mathrm{NO}_{3}{ }^{-}$in $8 \mathrm{WF}, 10.12$ $\mathrm{mg} \mathrm{N} \mathrm{kg}{ }^{-1}$ in average. Soil $\mathrm{NH}_{4}^{+}$was more affected in a short time after weeding practice was applied (Figure 2). The incorporation of weeds increased mineralized nitrogen (Chen et al., 2014; Utami et al., 2020). Mechanical weeding used in this study supported higher mineralization. Weeding frequencies impacted higher inorganic N. Furthermore, $\mathrm{NH}_{4}^{+}$content in soil is very important and needed most in the rice tillering period, especially the first 20 DAT (Sasaki et al., 2002). Yet, the highest $\mathrm{NH}_{4}^{+}$ in the organic field reached $6 \mathrm{WF}$ and $8 \mathrm{WF}$ at 51 DAT. 
Inorganic nitrogen in water

This study observed whether management applied in the rice fields would affect inorganic $\mathrm{N}$ content in water. Similar to soil inorganic nitrogen, the value of the concentration of $\mathrm{NH}_{4}^{+}$in water tend to be higher than the concentration of $\mathrm{NO}_{3}{ }^{-}$in water (Figure 4 and Figure 5). This may be contributed by the mineralization of dissolved organic matter in water becoming $\mathrm{NH}_{4}^{+}$and the conversion of $\mathrm{NO}_{3}^{-}$ to $\mathrm{NH}_{4}^{+}$. Continuously anaerobic conditions with abundant organic substrate and limited electron acceptor availability caused reduction of $\mathrm{NO}_{3}{ }^{-}-\mathrm{N}$ to $\mathrm{NH}_{4}^{+}$more efficient than $\mathrm{N}_{2}$ formation (Meng et al., 2014). Collected water from the inlet and outlet

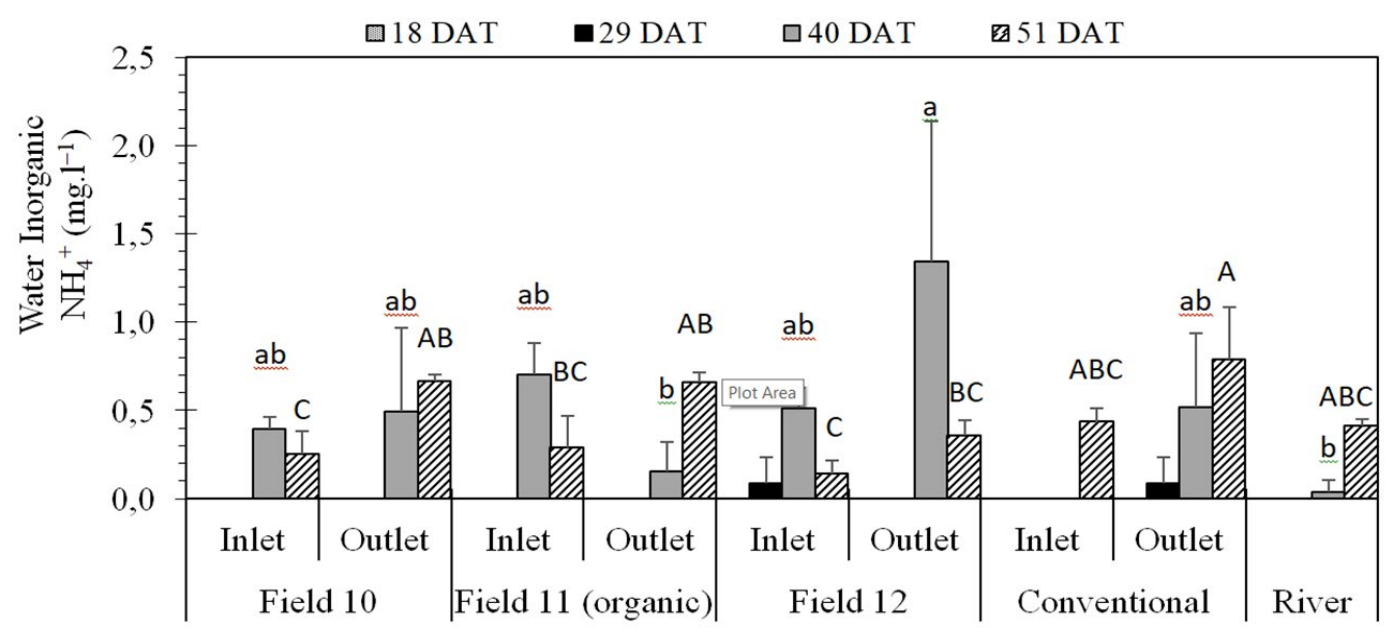

Figure 4. NH4+ concentration on water from inlet and outlet in east side of organic field (Field 10), organic field (Field 11), north side of organic field (Field 12), conventional, and river. Bars showed standard deviation ( $n=3)$. Letters above standard deviation bars showed significant difference at $p<0.05$ based on Tukey's HSD test each DAT.

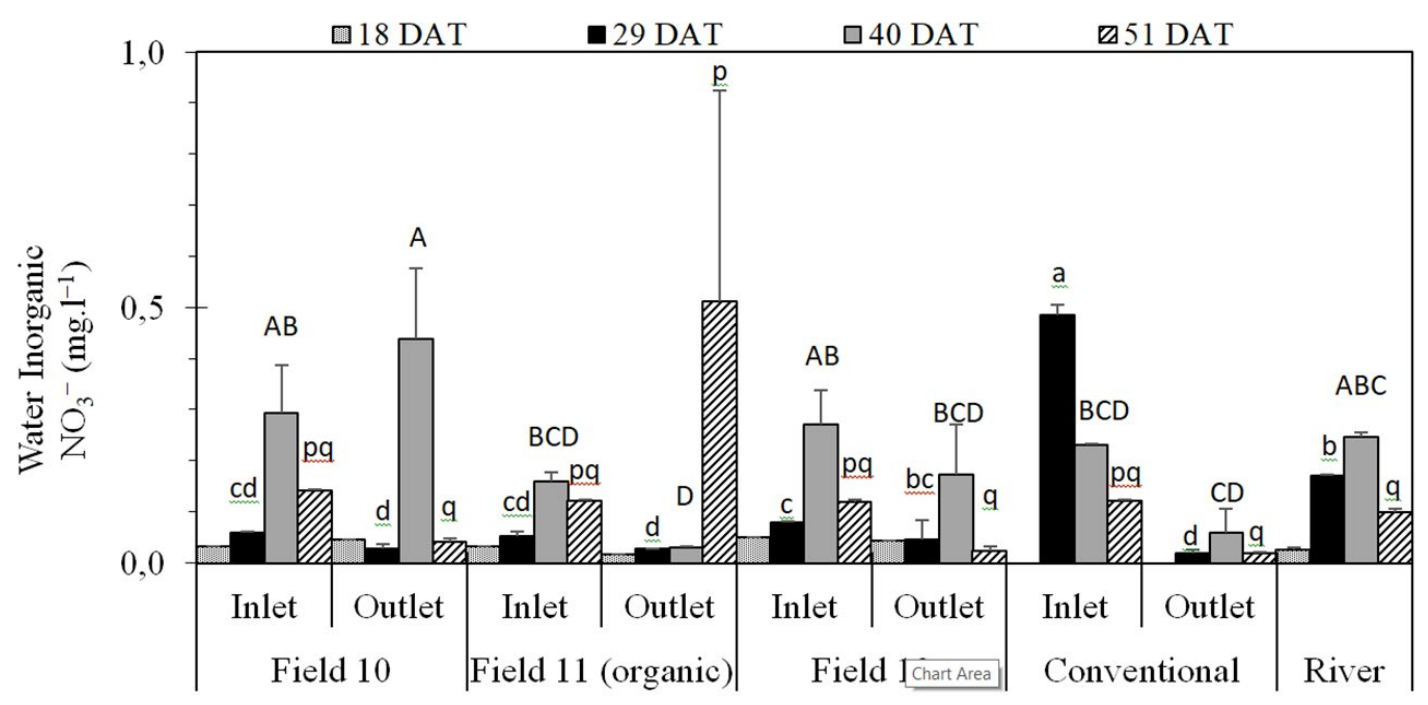

Figure 5. N03- concentration on water from inlet and outlet in east side of organic field (Field 10), organic field (Field 11), north side of organic field (Field 12), conventional, and river. Bars showed standard deviation ( $n=3)$. Letters above standard deviation bars showed significant difference at $p<0.05$ based on Tukey's HSD test each DAT. 
of the fields observed whether $\mathrm{NH}_{4}^{+}$and $\mathrm{NO}_{3}{ }^{-}$in water has significantly contributed to rice growth. Compared to water collected from field 10 and field 12 located adjacent to the organic field, the concentrations of $\mathrm{NH}_{4}^{+}$in the inlet of the organic fields received more or less similar concentrations (Figure 2). The concentration of $\mathrm{NO}_{3}{ }^{-}$collected from inlet of field 10 and field 12 showed an approximately similar concentration with the organic field (Figure 4). The water inlet and the outlet were located in each field. Those facts implied that each field has received an approximately similar amount of $\mathrm{NH}_{4}^{+}$and $\mathrm{NO}_{3}{ }^{-}$from the same source and may also indicate no water seepage among field 10 , organic field, and field $12 . \mathrm{NH}_{4}{ }^{+}$and $\mathrm{NO}_{3}{ }^{-}$concentration in organic fields water were approximately the same as conventional fields located across the river.

The concentration of $\mathrm{NH}_{4}^{+}$in outlet water of all fields tended to be higher than their inlet water and increased until 51 DAT. River water sample also showed a similar trend, which reached its highest $\mathrm{NH}_{4}^{+}$concentration in 51 DAT (Figure 4). The concentration of $\mathrm{NO}_{3}{ }^{-}$in river water reached its peak in 110 DAT (0.37 $\left.\mathrm{mg} \mathrm{N}^{-1}\right)$ (Figure 5). Concentration of $\mathrm{NO}_{3}{ }^{-}$in inletwater tended to be higher than outlet in all fields, except for organic field. Concentration of $\mathrm{NO}_{3}{ }^{-}$of the organic field showed higher in inlet water than outlet water, which was in a total of 0.699 and $0.468 \mathrm{mg} \mathrm{N}^{-1}$, respectively. Compared with the organic field, the conventional field indicated contrary, $\mathrm{NO}_{3}{ }^{-}$measured in the inlet was much higher than the outlet.

There was a change in the concentration of $\mathrm{NH}_{4}^{+}$and $\mathrm{NO}_{3}{ }^{-}$in inlet water and outlet water, indicating that $\mathrm{NH}_{4}^{+}$and $\mathrm{NO}_{3}{ }^{-}$dissolved in water was utilized by rice in organic and conventional fields. It seemed that the water can be a secondary source of $\mathrm{NH}_{4}^{+}$and $\mathrm{NO}_{3}{ }^{-}$for rice growth in organic and conventional fields. The concentra- tion of $\mathrm{NH}_{4}^{+}$in inlet and outlet water of organic field at 18 and 29 DAT were below the detectable value. In contrast, the concentration of $\mathrm{NO}_{3}{ }^{-}$in inlet and outlet water of organic fields at 18 and 29 DAT was lower than the other rice growth stage (40 and 51 DAT). In 18 and 29 DAT, rice was under the tillering stage. Weeding practices at those stages were very important in the organic fields since they became the main nitrogen source. The concentration of $\mathrm{NH}_{4}^{+}$in inlet water of conventional field at 18 and 29 DAT was lower than outlet water, whereas the concentration of $\mathrm{NH}_{4}^{+}$in inlet water of conventional field at 18 and 29 DAT was higher than outlet water. This may be related to applying inorganic fertilizer as a nitrogen source in conventional fields.

Both concentrations of $\mathrm{NH}_{4}{ }^{+}$and $\mathrm{NO}_{3}{ }^{-}$at 51 DAT were highest in the outlet of organic field, which was 0.66 and $0.51 \mathrm{mg} \mathrm{l}^{-1}$, respectively. Possible cause for this condition was the last weeding applied (at 49 DAT) in the field was the practice of weeding removal using rotary hoe that would stir weeds and surface soil. This practice was believed to impact on soil nitrogen fractions and aeration produced, then the mobility of nitrogen increased (Sudhalakshmi et al., 2005). As rice growth above 51 DAT was the time of stem elongation to panicle initiation, the need for nitrogen was decreased. Whereas, during a maximum tillering period (40 DAT), inlet water of organic field performed the highest peak of $\mathrm{NH}_{4}^{+}$between plots inlets. Whereas, in the same period conventional outlet reached the highest peak (1.29 $\left.\mathrm{mg} \mathrm{l}^{-1}\right)$ among other plots. Compared to the amount of soil available $\mathrm{NH}_{4}^{+}$ and $\mathrm{NO}_{3}{ }^{-}$of organic field and conventional field (Figures 2 and 3), the concentration of $\mathrm{NH}_{4}^{+}$and $\mathrm{NO}_{3}{ }^{-}$in the inlet or outlet water at 18, 29, 40, and 51 DAT in the conventional and organic field was much lower, which may indicate that the contri- 
bution of $\mathrm{NH}_{4}^{+}$and $\mathrm{NO}_{3}{ }^{-}$from water source was relatively insignificant. The source of inorganic nitrogen for rice growth was ultimately from soil available $\mathrm{NH}_{4}{ }^{+}$and $\mathrm{NO}_{3}{ }^{-}$due to weeding treatment. This finding indicated that weeding frequencies should become the component of good land management in organic agriculture.

\section{CONCLUSION}

Weeding frequencies influenced available soil $\mathrm{N}$, then impacted water inorganic $\mathrm{N}$ significantly instead of SOC and TN. Mechanical weeding applied potentially supported higher mineralization so that more weeding frequencies affected to higher soil inorganic $\mathrm{N}$. Water Inorganic $\mathrm{N}$ content showed that $\mathrm{NH}_{4}^{+}$value was higher than $\mathrm{NO}_{3}^{-}$. Thus, weeding frequencies are suitable alternative methods to support organic field management. Furthermore, we recommend 6WF as the most effective weeding frequency to supply more soil available $\mathrm{N}$ in organic rice farming.

\section{ACKNOWLEDGMENTS}

Margi Asih Maimunah, as the first author, acknowledges the Japan Students Services Organization (JASSO) to support studies in the Faculty of Agriculture, Yamagata University, Japan, from September 2019 to August 2020. Special thanks to all members of Soil Science and Plant Nutrition Laboratory, Faculty of Agriculture, Yamagata University for their cooperation during research, and all authors that contributed to this paper writing.

\section{REFERENCES}

Ardiantika, D. A., Purwanto, B. H., \& Utami, S. N. H. (2018). Effect of organic fertilizer on nitrogen uptake and yield of two different rice varieties in inceptisol, Kalitirto. IOP Conference Series: Earth and Environmental Science, 215, 012027. https://doi. org/10.1088/1755-1315/215/1/012027

Bajwa, A. A, Jabran, K., Shahid, M., Ali, H.H., Chauhan, B.S., \& Ehsanullah. 2015. Eco-biology and management of Echinochloa crus-galli. Crop Protection 75(2015): 151-162.
Bhatia, R, Mehta, S.K., Bhatia, J.K., Thakral, S.K. \& Rohila, A. (2016). Weed Management Knowledge of Organic Paddy Farmers of Haryana. Annals of Agri Bio Research. 21. 243-248.

Chauhan, B.S., Kumar, V., \& Mahajan, G. (2014). Research needs for improving weed management in rice. Indian Journal of Weed Science 46(1):1-3.

Chen, B., Liu, E., Tian, Q., Yan, C., \& Zhang, Y. (2014). Soil nitrogen dynamics and crop residues. A review. Agronomy for Sustainable Development, 34(2), 429-442. https://doi.org/10.1007/ $\underline{\mathrm{s} 13593-014-0207-8}$

de Rouw, A., \& Rajot, J.-L. (2004). Soil organic matter, surface crusting and erosion in Sahelian farming systems based on manuring or fallowing. Agriculture, Ecosystems \& Environment, 104(2), 263-276. https://doi.org/10.1016/j.agee.2003.12.020

Dewi, W. S., Wahyuningsih, G. I., Syamsiyah, J., \& Mujiyo. (2018). Dynamics of $\mathrm{N}-\mathrm{NH} 4+, \mathrm{N}-\mathrm{NO} 3$ - , and total soil nitrogen in paddy field with azolla and biochar. IOP Conference Series: Earth and Environmental Science, 142, 012014. https://doi. org/10.1088/1755-1315/142/1/012014

Hantush, M. M., Kalin, L., Isik, S., \& Yucekaya, A. (2013). Nutrient Dynamics in Flooded Wetlands. I: Model Development. Journal of Hydrologic Engineering, 18(12), 1709-1723. https://doi. org/10.1061/(ASCE)HE.1943-5584.0000741

Hazra, K. K., Swain, D. K., Bohra, A., Singh, S. S., Kumar, N., \& Nath, C. P. (2018). Organic rice: Potential production strategies, challenges and prospects. Organic Agriculture, 8(1), 39-56. https:// doi.org/10.1007/s13165-016-0172-4

Hikosaka, M., Iwahashi, F., \& Yamato, S. (2021). Metabolomic analysis of Schoenoplectus juncoides reveals common markers of acetolactate synthase inhibition among paddy weeds. Pesticide Biochemistry and Physiology, 174, 104827. https:// doi.org/10.1016/j.pestbp.2021.104827

Huang, M., Shan, S., Cao, F., Chen, J., \& Zou, Y. (2018). The potential of naturally occurring fallow weeds to scavenge nitrogen in rice cropping systems. Ecological Indicators, 93, 183-187. https:// doi.org/10.1016/j.ecolind.2018.05.002

Ishii, S., Ikeda, S., Minamisawa, K., \& Senoo, K. (2011). Nitrogen Cycling in Rice Paddy Environments: Past Achievements and Future Challenges. Microbes and Environments, 26(4), 282-292. https://doi.org/10.1264/jsme2.ME11293

Jerkins, D., \& Ory, J. 2016. National Organic Research Agenda. Outcomes and Recommendations from the 2015 National Organic Farmer Survey and Listening Sessions. Organic Farming Research Foundation. Canada.

Johnson, D. E., Wopereis, M. C. S., Mbodj, D., Diallo, S., Powers, S., \& Haefele, S. M. (2004). Timing of weed management and yield losses due to weeds in irrigated rice in the Sahel. Field Crops Research, 85(1), 31-42. https://doi.org/10.1016/S03784290(03)00124-2

Latif, A., Jilani, M. S., Baloch, M. S., Hashim, M. M., Khakwani, A. A., Khan, Q. U., Saeed, A., \& Mamoon-ur-Rashid, M. (2021). Evaluation of critical period for weed crop competition in growing broccoli crop. Scientia Horticulturae, 287, 110270. https://doi. org/10.1016/j.scienta.2021.110270

Li, M., Li, R., Zhang, J., Liu, S., Hei, Z., \& Qiu, S. (2019). A combination 
of rice cultivar mixed-cropping and duck co-culture suppressed weeds and pests in paddy fields. Basic and Applied Ecology, 40, 67-77. https://doi.org/10.1016/j.baae.2019.09.003

Liu, Y., Zhang, B., Li, C., Hu, F., \& Velde, B. (2008). Long-Term Fertilization Influences on Clay Mineral Composition and Ammonium Adsorption in a Rice Paddy Soil. Soil Science Society of America Journal, 72(6), 1580-1590. https://doi.org/10.2136/ sssaj2007.0040

Long, H.V., \& Yabe, M. (2011). The Impact of Environmental Factors on the Productivity and Efficiency of Rice Production: A Study in Vietnam's Red River Delta. European Journal of Social Sciences, 26(2), 218-230. http://www.europeanjournalofsocialsciences.com

Maimunah, M.A.; Kautsar, V.; Bimantara, P.O.; Kimani, S.M.; Torita, R.; Tawaraya, K.; Murayama, H.; Utami, S.N.H.; Purwanto, B.H.; Cheng,W. (2021). Weeding Frequencies Decreased Rice-Weed Competition and Increased Rice N Uptake in Organic Paddy Field. Agronomy 11 (1904), 1-12. https://doi.org/10.3390/ agronomy 11101904

Martínez-Eixarch, M., Curcó, A., \& Ibáñez, C. (2017). Effects of agri-environmental and organic rice farming on yield and macrophyte community in Mediterranean paddy fields. Paddy and Water Environment, 15(3), 457-468. https://doi.org/10.1007/ s10333-016-0563-x

Meng, F., Olesen, J.E., Sun, X., \& Wu, W. 2014. Inorganic Nitrogen Leaching from Organic and Conventional Rice Production on a Newly Claimed Calciustoll in Central Asia. PLoS ONE 9(5): e98138. doi:10.1371/journal.pone.0098138

Muthayya, S., Sugimoto, J. D., Montgomery, S., \& Maberly, G. F. (2014). An overview of global rice production, supply, trade, and consumption: Global rice production, consumption, and trade. Annals of the New York Academy of Sciences, 1324(1), 7-14. https://doi.org/10.1111/nyas.12540

Nguyen, T. T., Sasaki, Y., Kakuda, K., \& Fujii, H. (2020). Comparison of the nitrogen balance in paddy fields under conventional rice straw application versus cow dung compost application in mixed crop-livestock systems. Soil Science and Plant Nutrition, 66(1), 116-124. https://doi.org/10.1080/00380768.2019.1697856

Nojiri, Y., Kaneko, Y., Azegami, Y., Shiratori, Y., Ohte, N., Senoo, K., Otsuka, S., \& Isobe, K. (2020). Dissimilatory Nitrate Reduction to Ammonium and Responsible Microbes in Japanese Rice Paddy Soil. Microbes and Environments, 35(4), n/a. https://doi. org/10.1264/jsme2.ME20069

Oerke, E.-C., \& Dehne, H.-W. (2004). Safeguarding production-Losses in major crops and the role of crop protection. Crop Protection, 23(4), 275-285. https://doi.org/10.1016/j. сгорго.2003.10.001

Peng, Y., Cheng, X., Liu, D., Liu, X., Ma, G., Li, S., Yang, Y., Zhang, Y., \& Bai, L. (2021). Quintrione: A new selective herbicide for weed control in rice (Oryza sativa L.). Crop Protection, 141, 105501. https://doi.org/10.1016/j.cropro.2020.105501

Phukan, J., Kalita, S., \& Bora, P. (2021). Weed management in direct seeded rice: A review. Journal of Pharmacognosy and Phytocemistry, 10(2), 7.

Sahrawat, K. L. (2006). Organic Matter and Mineralizable Nitrogen Relationships in Wetland Rice Soils. Communications in Soil Science and Plant Analysis, 37(5-6), 787-796. https://doi. org/10.1080/00103620600564034
Sakuraoka, R., Toriyama, K., Kobayashi, K., Yamada, S., Kamioka, H., \& Mori, S. (2018). Incorporation of fallow weed increases phosphorus availability in a farmer's organic rice fields on allophanic Andosol in eastern Japan. Soil Science and Plant Nutrition, 64(3), 300-305. https://doi.org/10.1080/00380768.2018.1473006

Sardana, V., Mahajan, G., Jabran, K., \& Chauhan, B. S. (2017). Role of competition in managing weeds: An introduction to the special issue. Crop Protection, 95, 1-7. https://doi.org/10.1016/j. сгорго.2016.09.011

Sasaki, Y., Ando, H., \& Kakuda, K. (2002). Relationship between ammonium nitrogen in soil solution and tiller number at early growth stage of rice. Soil Science and Plant Nutrition, 48(1), 57-63. https://doi.org/10.1080/00380768.2002.10409171

Sudhalakshmi, C., Velu, V. \& Thiyagarajan, T.M. (2005). Weed Management Options on the Dynamics of Nitrogen Fractions in the Rhizosphere Soil of Rice Hybrids. Madras Agric. J. 92 (7-9) : 444-448

Tanaka, A., Toriyama, K., \& Kobayashi, K. (2012). Nitrogen supply via internal nutrient cycling of residues and weeds in lowland rice farming. Field Crops Research, 137, 251-260. https://doi. org/10.1016/j.fcr.2012.09.005

Toriyama, K., Amino, T., \& Kobayashi, K. (2020). Contribution of fallow weed incorporation to nitrogen supplying capacity of paddy soil under organic farming. Soil Science and Plant Nutrition, 66(1), 133-143. https://doi.org/10.1080/003807 $\underline{68.2020 .1716389}$

Uno, T., Tajima, R., Suzuki, K., Nishida, M., Ito, T., \& Saito, M. (2021). Rice yields and the effect of weed management in an organic production system with winter flooding. Plant Production Science, 1-13. https://doi.org/10.1080/134394 $\underline{3 X .2020 .1865823}$

Utami, A. I., Bimantara, P. O., Umemoto, R., Sabri, R. K., Kautsar, V., Tawaraya, K., Hanudin, E., \& Cheng, W. (2020). Incorporation of winter grasses suppresses summer weed germination and affects inorganic nitrogen in flooded paddy soil. Soil Science and Plant Nutrition, 66(2), 389-397. https://doi.org/10.1080 100380768.2020.1725914

Vats, S. (2015). Herbicides: History, Classification and Genetic Manipulation of Plants for Herbicide Resistance. In E. Lichtfouse (Ed.), Sustainable Agriculture Reviews (Vol. 15, pp. 153-192). Springer International Publishing. https://doi.org/10.1007/9783-319-09132-7 3

Wu, Z., Liu, Q., Li, Z., Cheng, W., Sun, J., Guo, Z., Li, Y., Zhou, J., Meng, D., Li, H., Yin, H. (2018). Environmental factors shaping the diversity of bacterial communities that promote rice production. BMC Microbiol 18 (51), 1-11. https://doi.org/10.1186/ s12866-018-1174-z

Zhang, Y. \& Scherer, H. W. (2000). Mechanisms of fixation and release of ammonium in paddy soils after flooding. Biology and Fertility of Soils, 31(6), 517-521. https://doi.org/10.1007/ $\underline{\mathrm{s} 003740000202}$ 